Miri Shefer-Mossensohn,

\title{
Science among the 0 ttomans: The Cultural Creation and Exchange of Knowledge
}

Austin: University of Texas Press, 2015, 260 p., 978-147-7303-59-7

History of science witnessed a revolutionary change in the second half of the twentieth century with a heightened focus on the social, political, and cultural setting that shaped production and circulation of scientific knowledge. This approach, which also raised questions about the definition of science, had an effect on the historical studies of science in the Ottoman Empire since the mid-1980s. Miri Shefer-Mossensohn's Science Among the Ottomans: The Cultural Creation and Exchange of Knowledge continues this approach as she attempts to fill a gap in English literature on sciences in the Ottoman Empire by writing an introductory text. Shefer-Mossensohn states that she is not interested in the content of sciences, but rather in the processes that produced "Ottoman science" (p. 11). By focusing on the subjects that Ottomans were interested in studying and the pedagogies they used, Shefer-Mossensohn hopes to provide an answer to Peter Dear's question "What is the history of science history of?" The author responds adopting a wide understanding of science as a "body of knowledge about the reality of our lives" (p. 1).

Science Among the Ottomans consists of an introduction, four chapters, and a conclusion. In the introduction, the author notes the historiographical shifts, and briefly reviews the secondary literature on Arabic-Islamic and Ottoman sciences. The first chapter deals with the concept of knowledge. Shefer-Mossensohn points out that Ottomans inherited sciences and knowledge from various civilizations including Turkic-Mongol, Chinese, Islamic, Byzantine, Mediterranean, and European civilizations. This is followed by diverging issues such as Seljukid decorative arts, contemporary Wahhabi understanding of the Prophetic hadith "Seek knowledge even in China," Ottoman gardening, the entry on knowledge in Meninski's thesaurus, epistemology, classifications of sciences, status of philosophical sciences, and amalgamation of diverging medical, astronomical and astrological bodies of knowledge. All of these show diversity of scientific traditions in the Ottoman Empire. 
In the second chapter, Shefer-Mossensohn discusses spaces and manners of learning in the Ottoman Empire. She begins with the issue of pedagogy regrettably without any engagement with primary sources. Then, the author counts autodidacticism, schooling in mektebs and medreses, tutoring at home, apprenticing in arts, training in palace, and modern military and civilian schools, among the ways of acquiring knowledge and learning in the Ottoman Empire. The author also observes that traveling in search of knowledge was common, and created links with other parts of the Muslim world. The issue of travel is taken up further in chapter three which focuses especially on the cross-cultural movement of knowledge as exemplified by translations, circulation of people, ideas, and objects. The chapter begins with issues of literacy and language, and continues with a description of calligraphic styles, and printing. Among the agents of knowledge, the reader is introduced to minorities including foreign nationals, Jews, and Phanariote Greeks. In this chapter, the discussion of Salonica as a cosmopolitan city is the most interesting, and provides a relatively richer discussion on the transfer of knowledge by the Jewish go-betweens (pp. 115-121).

Chapter four concerns the role of the state in the production of scientific knowledge and infrastructures. Shefer-Mossensohn describes patron-protégé relations which were crucial for the development of science and arts. Pious endowments (waqfs) are also noted for giving institutional support to schools and hospitals. The author observes that this traditional form of funding was used in nineteenth century hospitals which practiced modern medicine (pp. 132-135). In addition to medreses and hospitals, military education and technology was also patronized by the state. Ottoman state's investment was critical for development of particular sciences and technologies. In the conclusion, Shefer-Mossensohn presents a brief intellectual biography of Murtada al-Zabidi, and Abd al-Rahman al-Jabarti portraying them as "Ottoman scientists." The book concludes with a nuanced remark that, "Ottoman scientific experience was a complicated and evolving mosaic whose many different pieces coexisted in harmony, competitiveness, and tension" (p. 169). Despite such carefully crafted statements which abound in the book, there are some conceptual and substantive issues that cast a shadow on this significant endeavor.

Shefer-Mossensohn rightly criticizes the modern universalist understanding of science which had marred historians' treatment of the early modern or pre-modern knowledge systems. Based on a cultural approach, the author 
speaks of a unique "Ottoman science," and an "Ottoman mind." I find a tension between this singular conceptualization and the post-modern and pluralistic approach which informs the book in general. To put it differently, Shefer-Mossensohn presents a wide-ranging set of discourses and practices of sciences in the Ottoman domains. Yet, the author puts these diverse traditions together under the concept of "Ottoman science." This phrase was previously used by Ekmeleddin İhsanoğlu in order to refer to all kinds of scientific activities that took place in the Ottoman domains. Shefer-Mossensohn's appropriation of this notion unfortunately further complicates the idea of "Ottoman science" rather than advancing it in a critical way. If used more strictly to refer to scientific activities that were patronized by the Ottoman dynasty and the ruling elite as exemplified in chapter four of this book, it could serve as an analytical category.

Shefer-Mossensohn's engagement with primary sources is not at the level of her theoretical wit. While discussing pedagogy the author notes various genres that included this subject, yet, asserts that, "a glimpse at the Ottoman discourse on pedagogy is possible through Ottoman hagiography" (p. 58). The author's presentation of this genre itself is mediated through a secondary study. Hence, it is a curious matter that while being circumspect in avoiding generalizations regarding Ottoman medreses (p. 62) while lacking evidence, in this instance she does not hesitate to characterize Ottoman pedagogy as revolving around students' fear of punishment. The author also suggests that students did not have a good grasp of subjects they were memorizing. In fact, pedagogical texts from Islamic history and the Ottoman period clearly discouraged students from subjecting themselves to matters they did not comprehend. For instance, al-Zarnūjī warned students against recording matters they did not understand, and Saçaklizade went even further by discouraging students from listening to lectures beyond their comprehension. ${ }^{1}$ Kara Halil also stated that forced memorization without understanding was reprehensible. ${ }^{2}$ Although Shefer-Mossensohn aspires to present a complex history in general, neglecting relevant primary sources reduces the value of this undertaking.

I Sājaklīzādah, Muḥammad ibn Abī Bakr, and Muḥammad ibn Ismā'īl al-Sayyid Aḥmad, Tartīb al-ulūm (Bayrūt, Lubnān: Dār al-Bashāir al-Islāmīyah i988), p. 8I.

2 Kara Halil, Hashiya 'alā Jihat al-Wahda (Istanbul: al-Matba'at al-Amira I258 AH.), p. I4. 
The section on classifications of knowledge further exemplifies this problematic relationship with primary sources. In this section, the author merely mentions texts such as a library catalogue, Taşköprüzade and Katip Çelebi’s encyclopedic works without relating any classifications therein (pp. 34-37). The author notes one such classification into religious and rational sciences in passing. The reader remains curious if any variations existed among Ottoman scholars on this issue. A comparative analysis of the texts mentioned would have shown diversity even among these Ottoman scholars who represented the view from the imperial capital. For instance, the introduction of Katip Çelebi's Kashf al-Zunun (KZ) provides a rich discussion of the concept of 'ilm, and relates several classifications of sciences he deemed noteworthy. Shefer-Mossensohn uses $K Z$ in other contexts to contend that philosophical sciences were studied in the Ottoman Empire as witnessed by Çelebi's entry on 'ilm al-falsafiyat (pp. 44-45). She claims that this entry includes twenty-three titles, and only one of them is attributable to Anatolia insinuating that there was not any significant work on philosophy in the Ottoman heartlands. In fact, the said entry does not mention any essays. It seems that Shefer-Mossensohn counted the following alphabetical entries until the next section break without realizing that they were not part of that entry. Moreover, $K Z$ has a much longer entry on philosophy entitled "iilm al-hikma" which includes a history of these disciplines in the Ottoman Empire, and provides a different and more widespread classification of philosophical sciences.

Another infelicitous reading of texts is manifested in the author's claim that an eighteenth century curriculum by Nebi Efendizade shows that rational sciences were not included in the Ottoman colleges (p. 61). This is inaccurate as the author confuses a didactic poem of an anonymous scholar with that of Nebi Efendizade. In fact, Nebi Efendizade's curriculum includes both rational and religious sciences. To be fair, Shefer-Mossensohn attempts at showing that rational sciences did not receive the same level of interest in the Ottoman medreses in general, which is a point that could be granted by possibly using statistical research on the matter ${ }^{3}$ or further contextualizing why Ottomans needed to acquire those sciences in the first place.

3 See for instance, Seyfi Kenan, "III. Selim Dönemi Eğitim Anlayışında Arayışlar” in Nizâm-ı Kadîm'den Nizam-ı Cedìd'e: III. Selim ve dönemi = Selim III and his era: from ancien régime to new order (İstanbul: İSAM, 20IO), pp. I56-157. 
Although Shefer-Mossensohn's theoretical approach is more interesting than the substance of her arguments, to her credit, she does provide an alternative avenue for writing history of sciences in the Ottoman Empire. However, the history of "transmitted sciences" is still not integrated with that of "rational sciences." It is hoped that prospective studies on sciences in the Ottoman Empire will encompass all sciences, just as many Ottomans did.

\section{Kenan Tekin}

Yalova University

Hatice Aynur-A.Hilal Uğurlu (haz.),

\section{Ekrem Hakkı Ayverdi’nin Hâtırasına Osmanlı Mimarlık Kültürü,,}

İstanbul: Kubbealtı Yayınevi, 2016, 423 s., 978-605-4750-27-6.

Kubbealtı Yayınevi tarafından basılan Osmanlı Mimarlık Kültürü adlı kitap, içinde birer makalesi bulunan Hatice Aynur ve Hilal Uğurlu tarafından hazırlanmış olup, Osmanlı mimarlık tarihiyle ilgili anıtsal monografilerin yazarı Ekrem Hakkı Ayverdi'nin vefatının 30. yıldönümünde düzenlenen sempozyumda sunulan bildirilerin bir kısmını içermektedir. 22-23 Ekim 2014 tarihlerinde düzenlenen ve İ. Aydın Yüksel, M. Baha Tanman, Suna Çagaptay, Çiğdem Kafesçioğlu, Maximilian Hortmuth, Heath Lowry, Machiel Kiel, Selen Morkoç, Zeynep Yürekli Görkay, Nina Ergin, Hilal Uğurlu, Tülay Artan, Deniz Türker, Hakkı Önkal, Ezgi Dikici, İbrahim Numan, M. Zeki İbrahimgil, Sadettin Ökten, Hatice Aynur, Selçuk Mülayim, Ahmet Ersoy, Edhem Eldem ve Gülru Necipoğlu gibi yirmiden fazla bilim insanının sunduğu bildirilerden onikisi kitapta yayınlanmıştır.

Eser üç ana bölüm olarak tasarlanmıştır. "Mimarlık Kültürü ve Âdabını Yeniden Düşünmek" başlıklı birinci bölüm üç makaleden oluşmaktadır.

Gülru Necipoğlu, "Sinan Çağında Mimarlık Kültürü ve Âdab: Günümüze Yönelik Yorumlar” başlıklı bildirisinde (s. 19-66), Sinan’ın etnik kökenini tartışanların pek çoğunun 15-16.yüzyıl Osmanlı düzeni içinde Sinan ve patronlarının çoğunun devşirme sistemiyle Osmanlı bürokratik düzenine katıldıklarını 